\title{
A Comparative Study between Endoscopic Septoplasty and Conventional Septoplasty
}

\author{
ISLAM MA $^{\mathrm{a}}$, MOHAMMAD T $^{\mathrm{b}}, \mathrm{CHOWDHURY} \mathrm{NH}^{\mathrm{c}}$, MAMOON TB $^{\mathrm{d}}, \mathrm{KHAN} \mathrm{SR}^{\mathrm{e}}$, RAHMANASML $^{\mathrm{f}}$
}

\begin{abstract}
:
Background: Conventional nasal septal surgery depending on head light improves the nasal airway but leaves some complications, but with recent advancement in endoscopic approach limits the complication and improves the outcome. This is due to better visualization, improved illumination, avoiding unnecessary manipulation, limited exposure and scope for second surgery if required.
\end{abstract}

Aim and objective: To assess the functional outcome of endoscopic septoplasty over conventional septoplasty.

Material and method: This study was carried out in the department of Otolaryngology - Head \& Neck Surgery of Bangladesh Medical College Hospital and Popular Medical College Specialized Hospital over a period of 5 years (20142019). Ethical clearance was obtained from Hospital authority. All consecutive patients with symptomatic deviated nasal septum who were refractory to medical treatment were included in the study. Patients were equally divided into two groups of conventional and endoscopic septoplasty. Patients \& their attendants, or legal guardians (in patients of less than 18 years) were thoroughly briefed about the each operative procedure. Patients with acute rhinitis or allergic rhinitis or vasomotor rhinitis or upper respiratory tract infection, external deformity, patients unfit for surgeries and

Introduction:

Nasal obstruction is one of the most common presenting complaint to the otolaryngologist in their daily practice.

a. Prof. Md. Ashraful Islam, Professor and Head, Otolaryngology-Head \& Neck Surgery, Bangladesh Medical College

b. Dr. Tareq Mohammad, Assistant Registrar, ENT, Bangladesh Medical College

c. Dr. Nazmul Hossain Chowdhury, Assistant Professor, ENT, Bangladesh Medical College

d. Dr. Towsif Bin Mamoon, Assistant Registrar, ENT, Bangladesh Medical College

e. Dr. Saif Rahman Khan, Assistant Registrar, ENT, National Institute of ENT

f. Dr. ASM Lutfur Rahman, Resident Surgeon, Bangladesh Medical College Hospital

Address of Correspondence: Prof. Md. Ashraful Islam, Professor and Head, Otolaryngology-Head \& Neck Surgery, Bangladesh Medical College. Mobile 01711527954, E-mail ashrafis123@yahoo.com

Received: 06 June, 2020

Accepted: 04 March, 2021 patients not giving consent were excluded from the study. After surgery all patients were followed up monthly, 3 monthly and 6 monthly for 01 year. At each follow up visit, subjective and objective assessments were done. Objective assessment was done by Gertner-Podoshin plate and diagnostic nasal endoscopy.

Results: In this study, nasal obstruction was relieved in $91 \%$ of conventional and $95 \%$ in endoscopic septoplasty group. Headache was improved in $75.68 \%$ and $86.5 \%$ patients and snoring was improved in $79.5 \%$ \& $88.6 \%$ of patients of respectively. Intraoperative complications such as hemorrhage (21.67\% vs 3.33\%) and mucosal tear (28.33\% vs 5\%) are significantly higher in conventional septoplasty group than the endoscopy group.

Conclusion: The use of endoscope in septal surgery improves visualization, illumination, and thus reduces complication with improved functional outcome. It can be performed in other diseases of nose and para nasal sinus diseases in the perspective of functional endoscopic sinus surgery.

Keywords: Deviated nasal septum, Endoscope, Conventional septoplasty

(J Bangladesh Coll Phys Surg 2021; 39: 178-184) DOI: https://doi.org/10.3329/jbcps.v39i3.54160

Deviated nasal septum (DNS) is the most common structural malformation causing nasal obstruction of one or both nostrils. Different surgical techniques have been evolved so far for the correction of deviated septum by different surgeons since its inception. In 1947 Cottle described first conventional septoplasty ${ }^{1}$. It can be performed under local or general anesthesia using either a fiberoptic or a standard headlight. It is a conservative surgery in which only the deviated part of the septum is removed leaving behind as much cartilage and bone as possible.

The use of endoscope in septal surgery has significantly changed the concepts of septal surgery. It is a fastdeveloping concept and gaining popularity among the ENT surgeons. Nasal endoscopes were first used for septoplasty by Lanza et al. and Stammberger ${ }^{2,3}$ in 1991. Endoscopic septoplasty is a conservative surgery in which only the deviated portion of septum is removed 
leaving behind as much cartilage and bone as possible to maintain the structural and functional integrity of the nose.

It is a minimally invasive surgery that helps us to correct the septal deformity under direct visualization, using a naso-endoscope. Endoscopic approach under excellent illumination and magnification lessens the chance of injury to vital structures and hence lessens the complication ${ }^{4}$. This approach is particularly helpful for correction of posterior and high deviation and also helpful for any relevant nasal surgery if necessary. As Endoscopic septoplasty has many advantages, we compared it with conventional septoplasty to assess the functional outcome of these two methods.

\section{Materials and method:}

This study was carried out in the department of Otolaryngology - Head \& Neck Surgery of Bangladesh Medical College Hospital and Popular Medical College Specialized Hospital over a period of 5 years (2014-2019). Ethical clearance was obtained from Hospital authority. All consecutive patients with symptomatic deviated nasal septum who were refractory to medical treatment were included in the study.

Total procedure was described to the patient and their attendants/party; and adequate consents were obtained. Patients were randomly selected for surgical procedure and were divided into 2 equal groups of 60 patients. Computed Tomography (CT) scanning was done in all endoscopically selected group.

Patients were equally divided into two groups of conventional and endoscopic septoplasty. Patients \& their attendants, or legal guardians (in patients of less than 18 yeard) were thoroughly briefed about the each operative procedure.

\section{Inclusion criteria}

- Age more than 14 years.

- Patient with- symptomatic deviated nasal septum e.g. nasal obstruction, snoring, obstructive sleep apnea, headache etc.

- Patient reported with epistaxis

\section{Exclusion criteria}

- Patients with acute rhinitis or allergic rhinitis or vasomotor rhinitis or upper respiratory tract infection.

- External deformity with deviated nasal septum.
- Patients unfit for surgeries.

- Patients not giving consent.

\section{Procedure}

Technique for Endoscopic septoplasty

This procedure was performed under general anesthesia. After endotracheal intubation, both the nasal cavities were packed with a solution made with 3 ampule inj. Adrenaline (1:1000) and 15cc 2\% Xylocaine for 10 minutes to achieve nasal decongestion. Then the septum was infiltrated with a prepared solution of $2 \%$ xylocaine mixed adrenaline in a $1: 10,000$ to $1: 200,000$ concentration depending on the age and co-morbidity of the patient using $0^{\circ}$ rigid $4 \mathrm{~mm}$ endoscope. ${ }^{5}$ The injection was given from the posterior to anterior including the floor of the nasal cavity on both sides of the septum. Hemitransfixation was made on the convex side $5 \mathrm{~mm}$ away from the mucocutaneous junction. The mucoperichondrial and mucoperiosteal flaps were elevated using a suction elevator under direct visualization with an endoscope up to the floor to expose the deviated part of the septum completely as depicted on CT radiograph. Similarly the flaps were elevated from the opposite site with great precaution of septal flap tear. The most deviated part of the underlying exposed cartilage and bone were removed along with conchoplasty/turbinoplasty, when required. The flaps were then repositioned back and were stitched together from posterior to anterior directing to the upper part to avoid septal hematoma. Nasal merocele packs were given in both the nasal cavities without any nasal splints.

\section{Techniques for conventional septoplasty}

After infiltration with $2 \%$ xylocaine with adrenaline into septum and floor of the nasal cavity under headlight, hemitransfixion incision was made as the same to endoscopy group. The mucoperichondrial and periosteal flaps were elevated upto perpendicular plate of ethmoid. The osseocartilaginous junction was dislocated. A $0.5 \mathrm{~cm}$ of the anterior margin of perpendicular plate of ethmoid was removed with Luc's forceps. An inferior cartilaginous strip of $0.5 \mathrm{~cm}$ was removed with turbinectomy scissors. The incision was closed using chromic catgut (3-0), nasal splints were applied in both nasal cavities and anterior nasal packing were done with antibiotic impregnated ribbon gauze 


\section{Nasal pack/nasal splints}

- Endoscopic group: Merocele pack was removed on the same/ following day and the patient was discharged on the next day.

- Conventional group: Nasal pack was removed after 24 to 48 hours and discharged after 48 hours. Nasal splints were removed on the $7^{\text {th }}$ day in the outpatient department under local anesthesia.

- Saline nasal douching was advised after removal of nasal packs.

Follow-up

- Nasal cleaning with suction machine was done on $3^{\text {rd }}, 7^{\text {th }}$ and $14^{\text {th }}$ day to prevent nasal synechiae or any associated infections

- Then all patients were followed up monthly, 3 monthly and 6 monthly for 01 year

- At each follow up visit, subjective and objective assessment were done.

- Objective assessment was done by GertnerPodoshin plate and diagnostic nasal endoscopy.

Following parameters were noted on postoperative follow up

\section{Subjective}

- Nasal obstruction

- Headache

- Nasal discharge

- Hyposmia

- Nasal bleeding

\section{Objective}

- Persistence of anterior/posterior deviation or spur.

- Formation of synechiae.

- Persistent pathology of turbinate

- Presence of discharge in middle meatus.

- Any change in external nasal appearance.

\section{Results:}

Total 142 patients reported with symptoms which require septoplasty. 22 patients were excluded from the study because of different criteria. Finally 120 patients were included in this study with 60 patients in each group. In this study the male to female ratio for deviated nasal septum was 1.8:1 (Table 1). The most commonly affected subjects belonged to the 2nd and 3rd decade of life in both sexes. In the group that underwent conventional septoplasty, youngest patient was 16 year and the oldest was 55 years old. Among the patients who underwent endoscopic septoplasty, the youngest patient was 14 years and the oldest was 60 years old.
Nasal obstruction (100\%) and snoring (73.33\%) were the main symptoms of the amongst the study group. The clinical presentation of 120 patients are shown in Table II.

Anterior rhinoscopy and nasal endoscopic examination were done in all the patients. The findings are shown in Table III.

In this study group, $\mathrm{CT}$ scan was done in those patients who had middle turbinate hypertrophy or difficulty in evaluation of the middle meatus and posterior nasal cavity on endoscopic examination. CT findings are shown in Table IV.

Out of 120 patients with nasal obstruction, 112 patients were relieved of the symptom of which $91 \%$ belonged to conventional and $95 \%$ belonged to endoscopic septoplasty group. Headache was improved in $75.68 \%$ patients of conventional septoplasty group and $86.5 \%$ patients of endoscopic septoplasty group. Snoring was improved in $79.5 \%$ \& $88.6 \%$ of patients in both groups respectively. Table $\mathrm{V}$ shows the symptoms relived postoperatively. Immediate post-operative relief of symptoms like headache, snoring \& nasal discharge were significantly lower in Conventional group than Endoscopic goup. But no significant difference was found in relief of nasal obstruction, hyposmia \& epistaxis between these two groups.

Postoperative objective assessment of nasal patency was done by using Gertner-Podoshin plate at First follow up on $7^{\text {th }}$ day and later at $1^{\text {st }}, 3^{\text {rd }}$ and 6 th month.

Endoscopic assessment was carried out during their postoperative visit by $0^{\circ}$ endoscope after 03 months which is shown in Table VI. Other than persistent septal pathology, other findings were improved in the Endoscopic group significantly.

In this study, 13 patients in conventional septoplasty group had intraoperative hemorrhage and only 2 patients in the endoscopic septoplasty group had this. Mucosal tear occurred in 17 patients belonging to conventional septoplasty group and 3 patients belonging to endoscopic septoplasty group which is presented in Table VII. Both intraoperative complications were significantly lower in endoscopic septoplasty group.

Postoperative complications in both the group are presented in Table VIII which showed that there was no significant differences in post-operative septal perforation \& delayed healing at incision site between the two groups. But synechiae formation was significantly lower in endoscopic group than the conventional septoplasty group. 
Table-I

\begin{tabular}{lcccccc} 
& Age and gender $(n=120)$ \\
Gender & $10-20$ years & $21-30$ years & $31-40$ years & $41-50$ years & $51-60$ years & Total \\
\hline Male & $25(20.8 \%)$ & $34(28.3 \%)$ & $8(6.6 \%)$ & $7(5.8 \%)$ & $3(2.5 \%)$ & $77(64.1 \%)$ \\
Female & $15(12.5 \%)$ & $19(15.8 \%)$ & $5(4.2 \%)$ & $3(2.5 \%)$ & $1(0.8 \%)$ & $43(35.8 \%)$ \\
\hline Total & $40(33.3 \%)$ & $53(44.1 \%)$ & $13(10.8 \%)$ & $10(8.3 \%)$ & $4(3.3 \%)$ & 120 \\
\hline
\end{tabular}

Table-II

\begin{tabular}{lcc}
\multicolumn{3}{c}{$\begin{array}{c}\text { Major symptoms among study } \\
\text { population }(n=120)\end{array}$} \\
Symptom & Frequency & Percentage \\
\hline Nasal obstruction & 120 & 100 \\
Headache & 74 & 61.7 \\
Nasal discharge & 16 & 13.33 \\
Snoring & 88 & 73.33 \\
Hyposmia & 10 & 8.33 \\
Epistaxis & 8 & 6.66 \\
\hline
\end{tabular}

Table III

Anterior rhinoscopy \& diagnostic endoscopic findings $(n=120)$

\begin{tabular}{lcc} 
Findings & Number & Percentage \\
\hline Rt sided deviation & 56 & 46.67 \\
Lt sided deviation & 47 & 39.17 \\
Anterior deviation & 24 & 20 \\
Posterior deviation & 14 & 11.67 \\
Hypertrophied inferior turbinate & 43 & 35.83 \\
Spur & 10 & 8.33 \\
Hypertrophied middle turbinate & 35 & 29.16 \\
\hline
\end{tabular}

Table-IV

\begin{tabular}{lcc} 
& CT findings $(n=76)$ & \\
Findings & Number & Percentage \\
\hline Concha bullosa & 36 & 47.4 \\
Posterior deviation & 27 & 35.5 \\
High deviation & 15 & 19.7 \\
Pneumatized septum & 02 & 2.6 \\
\hline
\end{tabular}

Table-V

\begin{tabular}{lccccc}
\multicolumn{5}{c}{ Postoperative result: relief of symptoms $(n=120)$} & \\
Symptoms relieved & $\begin{array}{c}\text { Conventional } \\
\text { septoplasty }(\mathrm{n}=60)\end{array}$ & Percentage & $\begin{array}{c}\text { Endoscopic } \\
\text { septoplasty(n=60) }\end{array}$ & Percentage & $p$ value \\
\hline Nasal obstruction & $55 / 60$ & 91.67 & $57 / 60$ & 95 & 0.23 \\
Headache & $28 / 37$ & 75.68 & $32 / 37$ & 86.5 & 0.06 \\
Nasal discharge & $2 / 8$ & 25 & $6 / 8$ & 75 & $<0.001$ \\
Snoring & $35 / 44$ & 79.5 & $39 / 44$ & 88.64 & 0.08 \\
Hyposmia & $2 / 5$ & 40 & $3 / 5$ & 60 & 0.01 \\
Epistaxis & $4 / 4$ & 100 & $4 / 4$ & 100 & 0.5 \\
\hline
\end{tabular}

NB: $p$ value $<0.05$ is considered as significant 
Table-VI

\begin{tabular}{|c|c|c|c|c|c|}
\hline \multicolumn{6}{|c|}{ Endoscopic assessment at last follow up $(n=120)$} \\
\hline Findings & $\begin{array}{l}\text { Conventional } \\
\text { septoplasty } \\
(n=60)\end{array}$ & Percentage & $\begin{array}{l}\text { Endoscopic } \\
\text { septoplasty } \\
\quad(n=60)\end{array}$ & Percentage & $p$ value \\
\hline Persistent septal deviation & $5 / 60$ & 8.33 & $2 / 60$ & 3.33 & 0.12 \\
\hline Persistent pathology ofturbinate & $8 / 22$ & 36.36 & $2 / 21$ & 9.52 & 0.003 \\
\hline Discharge inmiddle meatus & $3 / 7$ & 42.86 & $0 / 8$ & 0 & $<0.001$ \\
\hline Persistent spur & $3 / 5$ & 60 & $0 / 5$ & 0 & $<0.001$ \\
\hline
\end{tabular}

$\mathrm{NB}: p$ value $<0.05$ is considered as significant

Table-VII

\begin{tabular}{lccccc} 
& \multicolumn{2}{c}{ Intraoperative complications } & & & \\
Complications & $\begin{array}{c}\text { Conventional } \\
\text { septoplasty }\end{array}$ & Percentage & $\begin{array}{c}\text { Endoscopic } \\
\text { septoplasty }\end{array}$ & Percentage & $p$ value \\
\hline Hemorrhage & 13 & 21.67 & 2 & 3.33 & 0.0007 \\
Mucosal tear & 17 & 28.33 & 3 & 5 & 0.0001 \\
\hline
\end{tabular}

NB: $p$ value $<0.05$ is considered as significant

Table-VIII

\begin{tabular}{|c|c|c|c|c|c|}
\hline \multicolumn{6}{|c|}{ Postoperative complications (n 120) } \\
\hline Complications & $\begin{array}{c}\text { Conventional } \\
\text { septoplasty }\end{array}$ & Percentage & $\begin{array}{l}\text { Endoscopic } \\
\text { septoplasty }\end{array}$ & Percentage & $p$ value \\
\hline Septal perforation & 2 & 3.33 & 0 & 0 & 0.75 \\
\hline Synechie & 4 & 6.67 & 0 & 0 & 0.019 \\
\hline Delayed healing at incision site & 2 & 3.33 & 3 & 5 & 0.323 \\
\hline
\end{tabular}

NB: $p$ value $<0.05$ is considered as significant

\section{Discussions:}

Nasal airway obstruction with or without snoring is one of the main complaints faced largely by the otolaryngologists in their day to day practice. Deviated nasal septum is the major cause of nasal obstruction. Correction of the deviated nasal septum has been done with various surgical procedures since its inception, starting from radical septal resection to mucosal preservation and subsequent preservation of the possible septal framework ${ }^{6}$. However, the concept of SMR was popularized; and refined by Killian and Freer separately in the early twentieth century had become the surgery of the septum ${ }^{7}$. But an increasing incidence of complications of septal surgery led to the more conservative surgical approach coined the term septoplasty and this technique have also been ended with many post-op complications ${ }^{8}$.

With the advent of nasal endoscope in the field of rhinology, it facilitates the accurate identification of the septal deviations, controlled elevation of the mucoperichondrial/mucoperosteal flap, removal of the only deviated part of the septum as well as proper reposition of the remaining septum draws the functional outcome better than previous conventional septoplasty with negligible complications. Then the endoscopic septoplasty is now a convincing alternative to the conventional septoplasty in the era of septal surgery ${ }^{9-11}$. In the present study, male to female ratio was 1.8:1 and the most common affected group were of younger age 
from 2nd \& 3 rd decades (Table I). This was in concordance with the study of Rao et al ${ }^{12}$. It is observed from this study that overall deviated nasal septum is more common in males because of the fact that in a country like ours this group tried to enroll themselves in the defense or allied services where many of them become unfit due to septal deviation.

The most common presentation (Table II) was nasal obstruction $(100 \%)$ which also was found in the study done by Saleim and Peacock ${ }^{13}, 14$. Snoring was present in $73.33 \%$ cases and headache was seen in $61.7 \%$ cases respectively. Hyposmia and epistaxis were seen in $8.33 \%$ and $6.66 \%$ of patients respectively; similar results were also seen in a study done by Gulati, Al Tawy and others ${ }^{15-17}$.

The relief of symptoms such as the nasal obstruction was improved in $91.67 \%$ (55/60) patients of conventional group and $95 \%$ (57) of endoscopy group, while relieved from post nasal discharge $25 \%$ (2/8) of the conventional group and $75 \%(6 / 8)$ of endoscopy group were recorded in our study. The headache was improved in 75\% (28/ 37) \& $86.5 \%(32 / 37)$ in both the patient groups respectively (Table V). Harley et al was observed significant improvement in patients with nasal obstruction and headache in endoscopic group as compared to conventional group ${ }^{18}$. In a study by Nayak et al, theendoscopic-aided septoplasty group was found to be more effective in correction of nasal symptoms such as nasal obstruction and headache ${ }^{19}$. Condition of snoring improved in conventional groups (7.5\%) and in the endoscopy group in $88.64 \%$ of patients. Epistaxis was relived in patients belonging to both groups. Concha bullosa, high and posterior deviation of the septum, pneumatic as well as thickened septum as evidenced on CT scanning (Table IV) can easily be addressed in endoscopic septoplasty ${ }^{20-21}$. The patients presented with snoring along with associated symptoms were relieved almost completely by endoscopic septoplasty which has been documented in this study.

In a study conducted by Park DH et al. complications were seen in $14.3 \%$ of the patients who underwent conventional septoplasty as compared to $0 \%$ in endoscopic correction of deviated nose ${ }^{22}$. In another study conducted by R Bothra et al. minor complications like hemorrhage, infra orbital edema and nasal pain were more in patients who underwent conventional septoplasty ${ }^{23}$. In this study, $13(21.7 \%)$ patients in conventional septoplasty group had intraoperative excessive hemorrhage while only $2(3.33 \%)$ patients in the endoscopic septoplasty group. Under endoscopic guidance peroperative bleeding points can easily be identified and controlled effectively; thus reduce the incidence of hemorrhage. Mucosal tear occurred in 17 (28.33\%) patients belonging to conventional septoplasty group and on the endoscopic septoplasty group, it was $3(5 \%)$. Regarding septal perforation, patients belonging to the conventional group had $2(3.33 \%)$ and none $0 \%$ in the endoscopic group. $4(6 \%)$ patients belonging to conventional septoplasty group reported with synechie formation but none in endoscopic group (Table VIII). This rate of complication was almost similar to several existing literatures ${ }^{24-26}$.

In this study it has been observed that due to clear visualization, isolated spurs can easily be seen that to avoid mucosal tear in endoscopic technique comparison to conventional septoplasty. The flaps inferior and posterior to the spur is relatively invisible leading to mucosal tears and excessive manipulation of tissues leading to synechiae formation in conventional method.

\section{Conclusion:}

It is evident from this study that endoscopic procedure ensures excellent visualization within the nasal cavity resulting minimum damage to the nasal and paranasal mucosa. This technique reduces the intraoperative hemorrhage and is easier to correct isolated septal spurs, posterior and highseptal deviation. Endoscopic septoplasty has the added advantage in performing other nasal and paranasal sinus diseases in the same sitting. Endoscopic septoplasty is an effective teaching tool and the procedure provides an excellent opportunity for observing and studying anatomy, pathology and surgical techniques that help in the training of assisting surgeons, graduate specialists, postgraduate and under graduate medical students.

\section{Disclosure}

The authors have no funding, financial relationships, or conflicts of interest to disclose.

\section{References:}

1. Cottle MH, Loring RM. Surgery on the nasal septum: New operative procedures aid indications. Ann OtolRhinolLaryngol 1948; 57: 705..https://doi.org/10.1177/00034894480 5700309 PMid:18885447 
2. Lanza DC, Kennedy DW, Zinreich SJ. Nasal endoscopy and its surgical application. In: Lee KJ, editor. Essential Otolaryngology: Head and Neck Surgery. 5th ed. New York: Medical Examination; 1991. P.373-87.

3. Stammberger H. Functional Endoscopic Sinus Surgery: The Messerklinger Technique. Philadelphia: BC Decker; 1991. P.432-3.

4. Manjunath R. is endoscopic septoplasty really superior to conventional septoplasty? National Journal of otolaryngology and HNS 2013 Aug1 (10), no 2.p-16-18.

5. Haung PH, Laughlin RB, Lanza DC, Kennedy DW. Endoscopic septoplasty: indications, technique and results. Otolaryngology Head Neck Surg 1999 May; 120(5): 67882.https://doi.org/10.1053/hn.1999.v120.a93047, PMid:10229592

6. Sathyaki DC, Geetha C, Manjuanth K. A Comparative Study of Endoscopic Septoplasty Versus Conventional Septoplasty. Indian J Otolaryngol Head Neck Surg 2014 Jun; 66(2): 155-161 https://doi.org/10.1007/s12070-0130692-0, PMid:24822154 PMCid:PMC4016353

7. Freer $\mathrm{O}$. The correction of deflections of the nasal septum with a minimum of traumation. J Am Med Association 1902; 38:636. https://doi.org/10.1001/jama.1902. $62480100012002 b$

8. Devaiah AK, Keojampa BK. Surgery of the Nasal septum. Rhinology and Facial Plastic Surgery 2009; 185: 181185.https://doi.org/10.1007/978-3-540-74380-4_15

9. Olphen AFV, Gleesan M, Browning GG, Burtan MJ, Hibbert J, Jones NS. Septum. In: scott brown's Otorhinolaryngology Head Neck Surg. 7th ed. Volume 2. Butterworth: Edword Arnold; 2008; 1577-1578.

10. Na'ara S. Traditional Septoplasty Vs Endoscopic Septoplasty for Treating Deviated Nasal Septum. Clinical Trials. Gov 2016; NCT02653950

11. Jain L, Jain M, Chouhan AN, Harshwardhan R. Conventional septoplasty verses endoscopic septoplasty:a comparative study. People's J Sci Res 2011; 4(2):24-8.

12. Rao JJ, Kumar ECV, Babu KR, Chowdary VS, Singh J, Rangamani SV: Classification of nasal septal deviationrelation to sinonasal pathology. Indian Journal of Otolaryngology \& Head and Neck Surgery, 2005; 57(3): 199-201.

13. Saleim MA. Endoscopic aided septoplasty versus conventional septoplasty. World J Med Sci. 2014;11(1):338 .

14. Peacock M. Submucous resection of the nasal septum. J Laryngol Otol 1981; 95:341. https://doi.org/10.1017/ S0022215100090812, PMid:7229517
15. Takahashi R, Ohbuchi T, Hohchi N, Takeuchi S, Ohkubo J, Ikezaki S, Suzuki H. Effect of Septoplasty and Turbiectomy on Obstructive sleep Apnea Syndrome. Nihon Jibiinkoka Gakkai Kahiho. 2013 Jul; 116 (7): 789-792.https://doi.org/ 10.3950/jibiinkoka.116.789, PMid:23980484

16. Gulati SP, Wadhera R, Ahuja N, Garg A, Ghai A. Comparative evaluation of endoscopic with conventional septoplasty. Indian J Otolaryngol Head Neck Surg 2009; 61:27-9. https:/ /doi.org/10.1007/s12070-009-0029-1, PMid:23120599. PMCid:PMC3450123

17. Tawy MAAF, Seleim A, elMonem MA, elgalilragab ABD. Endoscopic septoplasty: techniques and results. Al-azhar Assiut Med J 2014; 12(2).

18. Harley DH, Powitzky ES, Duncavage. Otolaryngology head \& neck surgery. J Clin Outcomes Surg Treatment Sinonasal Headache 2003; 129(3):217-21. https://doi.org/10.1016/ S0194-5998(03)00623-5

19. Nayak DR, Balakrishnan R, Murty KD. An endoscopic approach to the deviated nasal septum- a preliminary study. J Laryngol Otol 1998; 112:934-9. ,https://doi.org/10.1017/ S0022215100142124 PMid:10211215

20. Wotman M, Kacker A. What are the indications for the use of computed tomography before septoplasty? Laryngoscope 2016;126:1268-1270, https://doi.org/ 10.1002/lary.25815 PMid:26667897

21. Karadas D, Yuksel F, Senturk M, Dogan M. The contribution of computed tomography to nasal septoplasty. J Craniofac surg. 2013 sSep; 24 (5): 1549-51. https://doi.org/10.1097/ SCS.0b013e3182902729, PMid:24036724

22. Park DH, Kim TM, Han DG, Ahn KY (1998) Endoscopic assisted correction of deviated nose. Aesthetic Plast Surg 1998; 22:190-19, https://doi.org/10.1007/s002669900190, PMid:9618185

23. Bothra R, Mathur NN. Comparative evaluation of conventional versus endoscopic septoplasty for limited septal deviation and spur. J Laryngol Otol 2009; 123:737741 https://doi.org/10.1017/S0022215108004192, PMid: 19046471

24. Justyna DB, Piotr HS, Jwonna G, Complication in septoplasty based on a large group of 5639 patients. Eur Arch otolaryngol 2018; 275(7 ): 1789-1794 ,https:// doi.org/10.1007/s00405-018-4990-8 PMid:29770875, PMCid:PMC5992230

25. Manjunath Rao SV. Inferior Turbinectomy for Nasal Obstruction-Study of 219 Cases. National J Otorhinolaryngol Head Neck Surg 2013; 1(10):1370-5.

26. Talluri KK, Motru B. Correction of deviated nasal septum: conventional vs endoscopic septoplasty. J Dental Med Sci 2014; 13:14-5.https://doi.org/10.9790/0853-13521415 